\title{
Class C G protein-coupled receptors: reviving old couples with new partners
}

\author{
Thor C. Møller ${ }^{1}$, David Moreno-Delgado ${ }^{1}$, Jean-Philippe Pin ${ }^{1}$, Julie Kniazeff ${ }^{1}$ \\ ${ }^{1}$ Institut de Génomique Fonctionnelle (IGF), CNRS, INSERM, Univ. Montpellier, 34094 Montpellier, France
}

Received: 24 October 2016 / Accepted: 11 January 2017 / Published online: 28 February 2017

\begin{abstract}
G protein-coupled receptors (GPCRs) are key players in cell communication and are encoded by the largest family in our genome. As such, GPCRs represent the main targets in drug development programs. Sequence analysis revealed several classes of GPCRs: the class A rhodopsin-like receptors represent the majority, the class B includes the secretin-like and adhesion GPCRs, the class F includes the frizzled receptors, and the class $C$ includes receptors for the main neurotransmitters, glutamate and GABA, and those for sweet and umami taste and calcium receptors. Class $\mathrm{C}$ receptors are far more complex than other GPCRs, being mandatory dimers, with each subunit being composed of several domains. In this review, we summarize our actual knowledge regarding the activation mechanism and subunit organization of class C GPCRs, and how this brings information for many other GPCRs.
\end{abstract}

Keywords G protein-coupled receptors, Dimerization, Activation mechanism, Glutamate, GABA

\section{INTRODUCTION: CLASS C GPCRS AND TOPOLOGY}

The class C of G protein-coupled receptors (GPCRs) contains 22 members, including the eight metabotropic glutamate receptors $\left(\mathrm{mGlu}_{1-8}\right)$, the $\mathrm{GABA}_{\mathrm{B}}$ receptors $\left(\mathrm{GABA}_{\mathrm{B} 1}\right.$ and $\mathrm{GABA}_{\mathrm{B} 2}$ ), the calcium-sensing receptor $(\mathrm{CaS})$ and the taste receptors (T1R1-T1R3) (Fredriksson et al. 2003). The mGlu receptors have been further classified into three different groups depending on their similarities in sequence, pharmacology, signalling and localization: Group I includes mGlu $\mathrm{m}_{1}$ and $\mathrm{mGlu}_{5}$, Group II $\mathrm{mGlu}_{2}$ and $\mathrm{mGlu}_{3}$ and Group III mGlu $4, \mathrm{mGlu}_{6}, \mathrm{mGlu}_{7}$ and $\mathrm{mGlu}_{8}$.

Structurally, most class C GPCRs contain an extracellular so-called Venus flytrap (VFT) domain, a bilobed structure with a crevice between the two lobes that encloses the orthosteric binding site (Fig. 1). Agonist binding stabilizes a conformation with a shorter distance between the two lobes termed the closed conformation (Kunishima et al. 2000). The VFT domain is connected to the seven-transmembrane

Thor C. Møller and David Moreno-Delgado have contributed equally to the preparation of this review article.

$\triangle$ Correspondence: Jean-philippe.pin@igf.cnrs.fr (J.-P. Pin)
(7TM) domain through a cysteine-rich domain (CRD), which is notably absent in the $\mathrm{GABA}_{\mathrm{B}}$ receptor (Kunishima et al. 2000; Muto et al. 2007). The 7TM domain shares similarities with other class C GPCRs both in topology and in activating similar G proteins. In addition, class C GPCRs are either homodimers (e.g. mGlu receptors) or heterodimers (e.g. $\mathrm{GABA}_{\mathrm{B}}$ ) (Fig. 1). Here, we summarize the insights into the activation mechanism of this class of dimeric receptors gained in particular from structural and mutagenesis studies, and then we review the emerging evidence for new types of class C GPCR heterodimers or higher order oligomers.

\section{DIMERIZATION OF CLASS C GPCRS: A NECESSITY FOR SIGNAL TRANSDUCTION}

\section{Insights from homodimers: mGlu and CaS receptors}

mGlu and CaS receptors are prototypical homodimers that are stabilized by an inter-protomer disulphide bond, polar contacts between VFT domains and interactions between 7TM domains. The dimerization of 


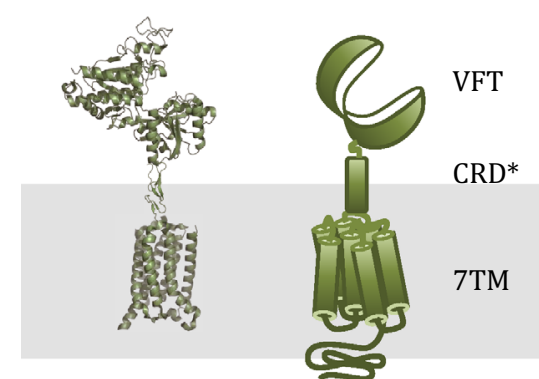

* Not present in the $G A B A_{B}$ receptor
Homodimers (ex. mGlu)

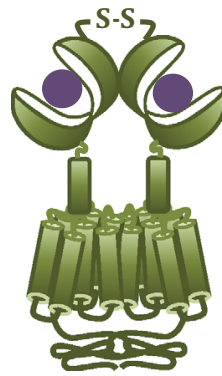

Endogeneous ligand

\section{Heterodimers \\ (ex. GABA $)_{B}$}

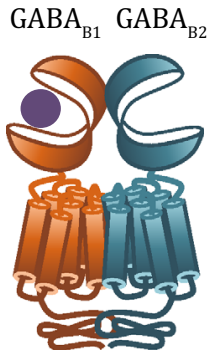

Fig. 1 Structural model and schematic representation of class $C$ GPCRs. Class C GPCRs are composed of a Venus flytrap (VFT) domain, a cysteine-rich domain (CRD) and a transmembrane (7TM) domain. This class of receptors forms obligatory dimers, either homodimers (e.g. mGlu) or heterodimers (e.g. $\mathrm{GABA}_{\mathrm{B}}$ )

these receptors is critical for promoting the activation mechanism, leading from agonist binding to $G$ protein activation. Indeed, different studies indicate that the conformation of one protomer is relative to the other changes upon activation, and this has been observed in all the structural domains found in class C GPCRs (Pin and Bettler 2016).

The dimer of VFT domains is in equilibrium between a resting and an active orientation, and agonist binding displaces the equilibrium towards the active state (Fig. 2). This reorientation is directly linked to G protein activation and, as a consequence, has been used to design a FRET-based sensor to monitor the receptor activation (Doumazane et al. 2013). Recently, singlemolecule analyses using either the isolated dimer of VFT domains or the full-length $\mathrm{mGlu}_{2}$ receptor dimer have confirmed that the VFT domains oscillate rapidly between the resting and active orientations (Olofsson et al. 2014; Vafabakhsh et al. 2015). In addition, the studies revealed that agonists with different efficacies diverge in their ability to shift the conformational equilibrium towards the fully active state, rather than stabilizing intermediate conformations.

Because reorientation of the VFT domain dimer is tightly linked to G protein activation, it is implied that this conformational change is somehow transmitted to the 7TM domains. The CRD has been shown to play a critical role in this process for mGlu receptors. This domain is highly rigid due to four intramolecular disulphide bonds (Muto et al. 2007), and disrupting them by mutagenesis impairs the capacity of orthosteric agonists to activate G proteins (Huang et al. 2011). In addition, crosslinking the two CRDs in a dimer results in a constitutively active receptor (Huang et al. 2011). Altogether, this indicates that the transmission from VFT to 7TM domain is mediated by the rigid CRDs coming into close proximity (Fig. 2).

At the 7TM domain level, activation of the receptor requires a rearrangement of the interface between the

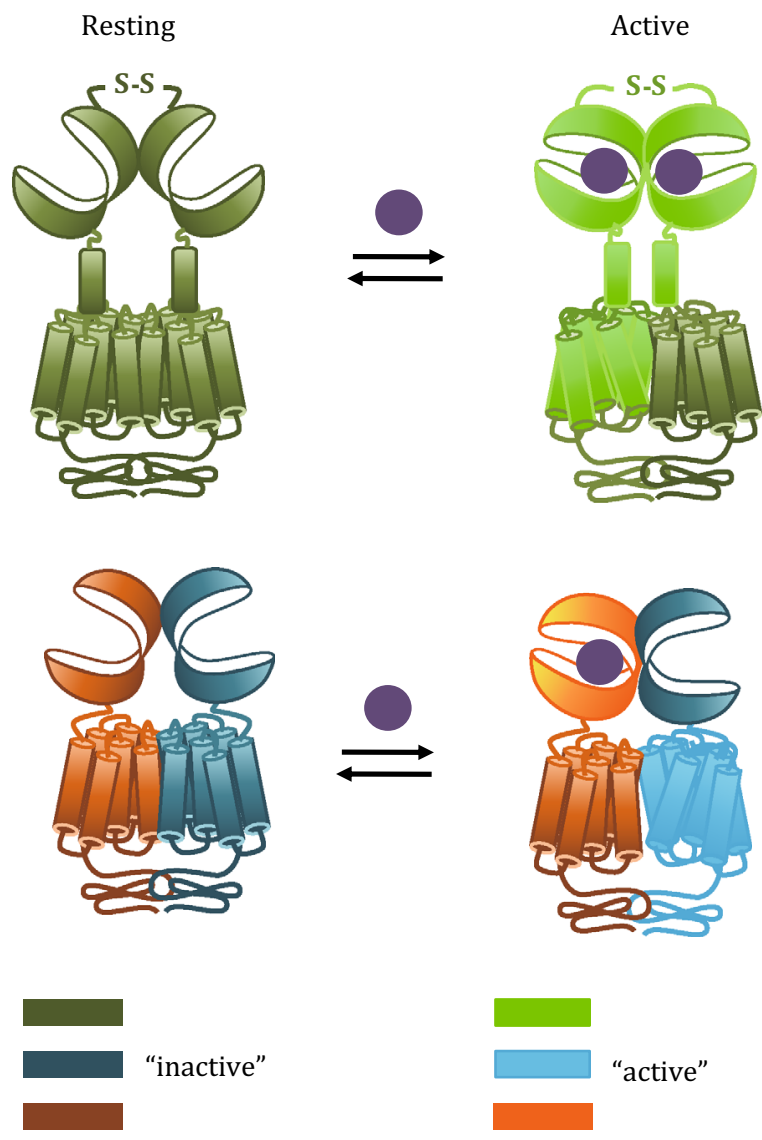

Fig. 2 Mechanism of activation of homodimers and heterodimers. Both homodimers and heterodimers undergo conformational changes upon activation. The relative orientation of the VFT dimer is changed upon agonist binding; the CRDs (not in $\mathrm{GABA}_{\mathrm{B}}$ ) are getting closer and the 7TM dimer changes conformation such that a single 7TM is in the active state 
7TM domains in the dimer. Actually, it has been shown for the $\mathrm{mGlu}_{2}$ receptor that this interface in the inactive state is formed by transmembrane helix 4 (TM4) and TM5 in each protomer, while the two TM6 s are facing each other in the active state (Xue et al. 2015). This major change in the dimer interface is required for receptor activity, demonstrated by locking the TM4TM5 interface, which prevents activation by agonist, and locking the TM6 interface, which leads to a constitutively active receptor (Xue et al. 2015). However, the crystal structure of the $\mathrm{mGlu}_{1}$ receptor 7TM domain in the presence of a negative allosteric modulator (NAM) suggested an alternative dimerization interface involving TM1 (Wu et al. 2014). While this difference might be attributed to crystal packing or lack of the VFT domain, further studies are required to determine whether a common mechanism describing the movement of the 7TM domain dimer can be defined for all class C GPCRs.

The data mentioned above suggest that the activation of mGlu receptors relies on the conformational changes of one protomer relative to the other one, which underlies the strict requirement of the mGlu dimerization for glutamate to activate G proteins (Fig. 2). This is further confirmed by experiments showing that glutamate fails to activate an isolated mGlu monomer reconstituted in nanodiscs whereas it activates an mGlu dimer (El Moustaine et al. 2012).

Several studies indicate that a single 7TM domain reaches the active conformation in an mGlu homodimer (Goudet et al. 2005; Hlavackova et al. 2005). In addition, an isolated mGlu monomer purified and reconstituted in nanodiscs activates $G$ proteins when stimulated by a positive allosteric modulator (PAM) (El Moustaine et al. 2012). Hence, in the context of a class C GPCR homodimer, $G$ proteins might be activated through the ligand-bound subunit (cis-activation) and/or through the other subunit (trans-activation). It has been shown for the $\mathrm{mGlu}_{5}$ receptor that Gq protein can be activated either by cis- or trans-activation (Brock et al. 2007). However, it is also possible that in some cases, depending on whether the receptor is cis- or transactivated, the pathways activated may differ. For instance, it has been observed using a combination of glutamate binding-deficient and $\mathrm{G}$ protein couplingdeficient receptors that the $\mathrm{mGlu}_{1}$ receptor triggers Gq-coupled signalling through cis- and trans-activation, while Gi/o and Gs are exclusively activated through cisactivation (Tateyama and Kubo 2011).

Another point to acknowledge when considering class C GPCR homodimers is cooperativity. It has been observed that although glutamate binding to one protomer could induce receptor activation, binding to both protomers was required for full activity (Kniazeff et al.
2004). In addition, binding to one protomer can induce negative cooperativity to the second protomer (Suzuki et al. 2004), which suggests additional complexity in mGlu receptor pharmacology.

Altogether, in class C GPCR homodimers, G protein activation can be achieved upon binding of a single agonist and by a single protomer with an active 7TM domain. However, the dimeric structure is an absolute prerequisite for the conformational transitions from endogenous agonist binding to $\mathrm{G}$ protein activation and thus for physiological receptor function.

\section{Insights from heterodimers: $\mathrm{GABA}_{\mathrm{B}}$ and T1Rs}

The $\mathrm{GABA}_{\mathrm{B}}$, sweet taste and umami taste receptors are prototypical class $\mathrm{C}$ heterodimers: two different subunits are required to activate $G$ proteins upon agonist binding, confirmed in vivo for the $\mathrm{GABA}_{\mathrm{B}}$ receptor by the disappearance of all physiological responses attributed to the heterodimer when either of the two subunits is knocked out (Prosser et al. 2001; Schuler et al. 2001; Queva et al. 2003; Zhao et al. 2003; Gassmann et al. 2004). The $G_{A B A}$ B receptor is a non-covalently linked obligatory heterodimer composed of the subunits $\mathrm{GABA}_{\mathrm{B} 1}$ and $\mathrm{GABA}_{\mathrm{B} 2}$ (Jones et al. 1998; Kaupmann et al. 1998; White et al. 1998), while the taste receptors are composed of T1R3 and either T1R1 or T1R2 resulting in umami or sweet taste receptors, respectively (Nelson et al. 2001, 2002) (Fig. 1). For the $\mathrm{GABA}_{\mathrm{B}}$ receptor, the $\mathrm{GABA}_{\mathrm{B} 1}$ subunit contains the binding site for orthosteric ligands (Galvez et al. 1999, 2000), while the $\mathrm{GABA}_{\mathrm{B} 2}$ subunit is necessary for $G$ protein activation (MargetaMitrovic et al. 2001a; Robbins et al. 2001; Duthey et al. 2002), confirming the absolute necessity of heterodimer formation. In contrast, the T1R2 subunit seems to be responsible for binding of most ligands and for $\mathrm{G}$ protein activation in the sweet taste receptor $(\mathrm{Xu}$ et al. 2004). Interestingly, the attempt to create a homomeric receptor by fusing the ligand binding and the $G$ protein coupling domains from $\mathrm{GABA}_{\mathrm{B}}$ resulted in a non-functional receptor (Galvez et al. 2001), indicating a unique activation mechanism for these heterodimeric receptors.

In the $\mathrm{GABA}_{\mathrm{B}}$ receptor, the correct assembly of the heterodimer is ensured by the C-terminal tail: when expressed alone, $\mathrm{GABA}_{\mathrm{B} 1}$ is retained in the ER due to a RSRR retention motif located in its C-terminal tail (Couve et al. 1998; Margeta-Mitrovic et al. 2000; Pagano et al. 2001). In the presence of $\mathrm{GABA}_{\mathrm{B} 2}$, the retention motif is masked by a coiled-coil interaction between the subunits, thus ensuring that only correctly assembled heterodimers are trafficked to the cell surface (MargetaMitrovic et al. 2000; Pagano et al. 2001). However, functional $\mathrm{GABA}_{B}$ receptors can assemble on the cell 
surface independently of the coiled-coil domains (Pagano et al. 2001). In addition to the coiled-coil domain interaction, the $\mathrm{GABA}_{\mathrm{B}}$ subunits form interactions between the VFT domains (Geng et al. 2013) and most likely also the 7TM domains. Crystal structures of the $\mathrm{GABA}_{\mathrm{B}}$ VFT dimer show that in the resting state, they interact exclusively via a tight interface involving only one lobe, whereas in the active state a reorientation of the $\mathrm{GABA}_{\mathrm{B} 1}$ VFT domain facilitates an additional, looser interaction between the second lobes (Geng et al. 2013).

During activation, agonists bind to the VFT domain of one protomer and promote active conformation of the 7TM domain of the other protomer (Galvez et al. 2001; Margeta-Mitrovic et al. 2001b), implying that trans-activation is the main process for $G$ protein activation in these heterodimers (Fig. 2). Compared to homodimers, this results from a slightly different mechanism. For example, in the $\mathrm{GABA}_{\mathrm{B}}$ receptor, the $\mathrm{GABA}_{\mathrm{B} 2}$ VFT domain is unable to bind ligands (Kniazeff et al. 2002) and its closed conformation is not necessary for full activation (Geng et al. 2012). Total deletion of the $\mathrm{GABA}_{\mathrm{B} 2}$ VFT domain results in a functional receptor suggesting that the signal can proceed from the $\mathrm{GABA}_{\mathrm{B} 1}$ VFT domain to the $\mathrm{GABA}_{\mathrm{B} 2}$ 7TM domain through the $\mathrm{GABA}_{\mathrm{B} 1}$ 7TM domain (Monnier et al. 2011). On the other hand, replacing the $G_{A B A} A_{B 1} 7 T M$ domain by a single transmembrane helix also produced a functional receptor, suggesting that the signal may also be transmitted through the $\mathrm{GABA}_{\mathrm{B} 2}$ VFT domain (Monnier et al. 2011). Altogether, these data propose that two ways of activation exist in the $\mathrm{GABA}_{B}$ receptor.

Cooperativity between protomers exists also in class $C$ GPCR heterodimers. It has been shown in the GABA receptor that although the $\mathrm{GABA}_{\mathrm{B} 2}$ VFT and the GABA $\mathrm{B}_{1}$ 7TM domains are not directly involved in ligand binding and $G$ protein activation, they play a key role in defining the activation potency. Indeed, when expressed alone, $\mathrm{GABA}_{\mathrm{B} 1}$ exhibits low-affinity agonists binding; however, when co-expressed with $\mathrm{GABA}_{\mathrm{B} 2}$, the interaction with the $\mathrm{GABA}_{\mathrm{B} 2}$ VFT domain increases agonist affinity tenfold (Kaupmann et al. 1998). Along the same lines, the $\mathrm{GABA}_{\mathrm{B} 1} 7 \mathrm{TM}$ domain improves the $\mathrm{G}$ protein coupling efficiency of $\mathrm{GABA}_{\mathrm{B} 2}$ (Galvez et al. 2001).

Altogether, in class C GPCR heterodimers, such as the $\mathrm{GABA}_{\mathrm{B}}$ receptor, one subunit contains the ligand binding domain, but the other subunit is critical for high-affinity agonist binding and functional responses. For the $\mathrm{GABA}_{\mathrm{B}}$ receptor, the necessity of dimerization and allosteric transition is ensured by specific targeting of the heterodimer to the cell surface.

\section{NEW FOLKS IN CLASS C GPCR OLIGOMERS}

\section{Heterodimers of mGlu receptors}

In addition to homodimers, mGlu receptors have recently been reported to possibly form eleven different heterodimers in heterologous systems: the $\mathrm{mGlu}_{1}$ and $\mathrm{mGlu}_{5}$ receptors can only heteromerize between them, whereas all combinations are possible among five other mGlu receptors $\left(\mathrm{mGlu}_{2}, \mathrm{mGlu}_{3}, \mathrm{mGlu}_{4}, \mathrm{mGlu}_{7}\right.$ and $\mathrm{mGlu}_{8}$ ) (Doumazane et al. 2011). These various combinations are likely strict heterodimers and not the result of association of two homodimers as well demonstrated for the $\mathrm{mGlu}_{2}-\mathrm{mGlu}_{4}$ combination (Yin et al. 2014; Niswender et al. 2016). Interestingly, all possible combinations were found between receptors that share neuronal localization and $G$ protein coupling, which suggests that heterodimer formation is not an artefact of receptor co-expression, but a specific process controlled by structural and functional properties of the receptors.

The study of mGlu heterodimers is a difficult issue to address due to two main points: the lack of specific ligands (especially for receptors from the same group) and the presence of both homodimers and heterodimers in cells co-expressing two mGlu receptors (Doumazane et al. 2011). However, some studies have tried to address the topic focusing on heterodimers between $\mathrm{mGlu}_{2}$ and $\mathrm{mGlu}_{4}$ receptors. Although the precise function and pharmacological properties of these heterodimers in native tissues remain open questions, $\mathrm{mGlu}_{2}$ and $\mathrm{mGlu}_{4}$ receptors were found to co-immunoprecipitate in rat dorsal striatum and medial prefrontal cortex (Yin et al. 2014). Regarding orthosteric agonist activation, partial agonists such as DCG-IV seem to have a reduced effect in heterodimer activation in comparison with mGlu ${ }_{2}$ homodimers (Kammermeier 2012), and full agonists such as LY379268 seem to be less potent in activating $\mathrm{mGlu}_{2}-\mathrm{mGlu}_{4}$ heterodimers and exhibit dose-response curves with reduced slope (Yin et al. 2014). Regarding heterodimer activation by PAMs, $\mathrm{mGlu}_{2}$ PAMs do not activate the heterodimer (Kammermeier 2012), whereas the effect of $\mathrm{mGlu}_{4}$ PAMs depends strongly on their scaffold: VU0155041 seems to activate the heterodimer, but not PHCCC (Yin et al. 2014) or VU0418506 (Niswender et al. 2016). Further research in the binding site of these PAMs could lead to compounds activating only $\mathrm{mGlu}_{2 / 4}$ heterodimers, which could help to understand their physiological role.

\section{Higher order $\mathrm{GABA}_{B}$ oligomers}

The existence of higher order oligomers of GPCRs is still a topic open for discussion, especially because most of 
the observations have been done in heterologous cells and not validated in native tissues (Vischer et al. 2015). However, increasing experimental evidence suggests that the $\mathrm{GABA}_{\mathrm{B}}$ receptor forms oligomers larger than heterodimers. First, in time-resolved FRET experiments, a strong FRET signal was measured between $\mathrm{GABA}_{\mathrm{B} 1}$ subunits, whereas the signal between $\mathrm{GABA}_{\mathrm{B} 2}$ subunits was weak. This led to the proposal that the $\mathrm{GABA}_{\mathrm{B}}$ receptor forms at least dimers of heterodimers associated through the $\mathrm{GABA}_{\mathrm{B} 1}$ subunits (Maurel et al. 2008; Comps-Agrar et al. 2011, 2012). Notably, the FRET/receptor ratio was constant over a wide range of receptor densities, including expression levels similar to the endogenous levels in the brain (Maurel et al. 2008). In addition, the existence of oligomers larger than tetramers was suggested by single-molecule microscopy experiments in $\mathrm{CHO}$ cells, which showed that at low densities, the majority of $\mathrm{GABA}_{\mathrm{B}}$ receptors were dimers with a smaller population $(\sim 30 \%)$ of tetramers, whereas at higher densities the dimer population disappeared and complexes larger than tetramers appeared, representing $\sim 60 \%$ at the highest density (Calebiro et al. 2013).

In native tissues, the existence of $\mathrm{GABA}_{\mathrm{B}}$ oligomers is more complex to prove, but some evidence supports the proposal. Indeed, a FRET signal between anti-GABA $A_{\mathrm{B} 1 \mathrm{a}}$ antibodies was detected in brain membrane from wildtype animals, but not from $\mathrm{GABA}_{\mathrm{B} 1 \mathrm{a}}$ knockout animals (Comps-Agrar et al. 2011), and the migration of $\mathrm{GABA}_{\mathrm{B}}$ receptors from brain membranes on native gels is consistent with complexes larger than dimers (Schwenk et al. 2010).

A possible function of the oligomerization of the $\mathrm{GABA}_{\mathrm{B}}$ heterodimer is modulation of receptor signalling. Indeed, it was found that inhibiting $\mathrm{GABA}_{\mathrm{B} 1}-\mathrm{GABA}_{\mathrm{B} 1}$ interactions using either a non-functional $\mathrm{GABA}_{\mathrm{B} 1}$ subunit as competitor or introducing a mutation in the $\mathrm{GABA}_{\mathrm{B} 1}$ VFT domain increased signalling efficacy by approximately 50\% (Maurel et al. 2008; Comps-Agrar et al. 2011). It was further shown that one ligand or one $\mathrm{G}$ protein per oligomer was sufficient to achieve full activation, suggesting negative cooperativity between heterodimers (Comps-Agrar et al. 2011).

\section{CONCLUSIONS}

Class C GPCRs are acknowledged to be dimeric. Over the last two decades, an increasing number of studies have shed light on the necessity of this dimerization for their mechanism of activation. These studies also proposed general concepts for the activation of GPCR dimers. In recent years, new combinations of class C GPCRs with specific pharmacological properties have been reported in heterologous systems and may reveal an even higher complexity of the glutamatergic and GABAergic modulation of the synaptic activity.

$\begin{array}{ll}\text { Abbreviations } & \\ \text { 7TM domain } & \text { Seven-transmembrane domain } \\ \text { CaS receptor } & \text { Calcium-sensing receptor } \\ \text { CRD } & \text { Cysteine-rich domain } \\ \text { GABA } & \gamma \text {-Aminobutyric acid } \\ \text { GPCR } & \text { G protein-coupled receptor } \\ \text { mGlu receptor } & \text { Metabotropic glutamate receptor } \\ \text { NAM } & \text { Negative allosteric modulator } \\ \text { PAM } & \text { Positive allosteric modulator } \\ \text { TM } & \text { Transmembrane } \\ \text { VFT } & \text { Venus flytrap }\end{array}$

Acknowledgements This work was supported by the CNRS, INSERM and Univ Montpellier, and by grants from the Agence National de la Recherche (ANR-12-BSV2-0015; ANR-13-RPIB0009), the Fondation Recherche Médicale (FRM DEQ 20130326522). TCM was supported by a funding from the European Union's Seventh Framework Programme for research, technological development and demonstration under grant agreement no 627227 .

\section{Compliance with ethical standards}

Conflict of interest Thor C. Møller, David Moreno-Delgado, JeanPhilippe Pin and Julie Kniazeff declare that they have no conflict of interest.

Human and animal rights and informed consent This review article does not contain any studies with human or animal subjects performed by any of the authors.

Open Access This article is distributed under the terms of the Creative Commons Attribution 4.0 International License (http:// creativecommons.org/licenses/by/4.0/), which permits unrestricted use, distribution, and reproduction in any medium, provided you give appropriate credit to the original author(s) and the source, provide a link to the Creative Commons license, and indicate if changes were made.

\section{References}

Brock C, Oueslati N, Soler S, Boudier L, Rondard P, Pin JP (2007) Activation of a dimeric metabotropic glutamate receptor by intersubunit rearrangement. J Biol Chem 282:33000-33008

Calebiro D, Rieken F, Wagner J, Sungkaworn T, Zabel U, Borzi A, Cocucci E, Zurn A, Lohse MJ (2013) Single-molecule analysis of fluorescently labeled G-protein-coupled receptors reveals complexes with distinct dynamics and organization. Proc Natl Acad Sci USA 110:743-748

Comps-Agrar L, Kniazeff J, Nørskov-Lauritsen L, Maurel D, Gassmann M, Gregor N, Prézeau L, Bettler B, Durroux T, 
Trinquet E, Pin JP (2011) The oligomeric state sets $\mathrm{GABA}_{\mathrm{B}}$ receptor signalling efficacy. EMBO J 30:2336-2349

Comps-Agrar L, Kniazeff J, Brock C, Trinquet E, Pin JP (2012) Stability of $\mathrm{GABA}_{\mathrm{B}}$ receptor oligomers revealed by dual TR-FRET and drug-induced cell surface targeting. FASEB J 26:3430-3439

Couve A, Filippov AK, Connolly CN, Bettler B, Brown DA, Moss SJ (1998) Intracellular retention of recombinant $\mathrm{GABA}_{\mathrm{B}}$ receptors. J Biol Chem 273:26361-26367

Doumazane E, Scholler P, Zwier JM, Trinquet E, Rondard P, Pin JP (2011) A new approach to analyze cell surface protein complexes reveals specific heterodimeric metabotropic glutamate receptors. FASEB J 25:66-77

Doumazane E, Scholler P, Fabre L, Zwier JM, Trinquet E, Pin JP, Rondard P (2013) Illuminating the activation mechanisms and allosteric properties of metabotropic glutamate receptors. Proc Natl Acad Sci USA 110:E1416-E1425

Duthey B, Caudron S, Perroy J, Bettler B, Fagni L, Pin JP, Prezeau L (2002) A single subunit (GB2) is required for G-protein activation by the heterodimeric $\mathrm{GABA}_{\mathrm{B}}$ receptor. J Biol Chem 277:3236-3241

El Moustaine D, Granier S, Doumazane E, Scholler P, Rahmeh R, Bron P, Mouillac B, Baneres JL, Rondard P, Pin JP (2012) Distinct roles of metabotropic glutamate receptor dimerization in agonist activation and G-protein coupling. Proc Natl Acad Sci USA 109:16342-16347

Fredriksson R, Lagerstrom MC, Lundin LG, Schioth HB (2003) The G-protein-coupled receptors in the human genome form five main families. Phylogenetic analysis, paralogon groups, and fingerprints. Mol Pharmacol 63:1256-1272

Galvez T, Parmentier ML, Joly C, Malitschek B, Kaupmann K, Kuhn R, Bittiger H, Froestl W, Bettler B, Pin JP (1999) Mutagenesis and modeling of the $\mathrm{GABA}_{\mathrm{B}}$ receptor extracellular domain support a venus flytrap mechanism for ligand binding. J Biol Chem 274:13362-13369

Galvez T, Prézeau L, Milioti G, Franek M, Joly C, Froestl W, Bettler B, Bertrand HO, Blahos J, Pin JP (2000) Mapping the agonistbinding site of $\mathrm{GABA}_{\mathrm{B}}$ type 1 subunit sheds light on the activation process of $\mathrm{GABA}_{\mathrm{B}}$ receptors. J Biol Chem 275:41166-41174

Galvez T, Duthey B, Kniazeff J, Blahos J, Rovelli G, Bettler B, Prézeau L, Pin JP (2001) Allosteric interactions between GB1 and GB2 subunits are required for optimal $\mathrm{GABA}_{\mathrm{B}}$ receptor function. EMBO J 20:2152-2159

Gassmann M, Shaban H, Vigot R, Sansig G, Haller C, Barbieri S, Humeau Y, Schuler V, Muller M, Kinzel B, Klebs K, Schmutz M, Froestl W, Heid J, Kelly PH, Gentry C, Jaton AL, Van der Putten H, Mombereau C, Lecourtier L, Mosbacher J, Cryan JF, Fritschy JM, Lüthi A, Kaupmann K, Bettler B (2004) Redistribution of $\mathrm{GABA}_{\mathrm{B}(1)}$ protein and atypical $\mathrm{GABA}_{\mathrm{B}}$ responses in $\mathrm{GABA}_{\mathrm{B}(2)^{-}}$ deficient mice. J Neurosci 24:6086-6097

Geng Y, Xiong D, Mosyak L, Malito DL, Kniazeff J, Chen Y, Burmakina S, Quick M, Bush M, Javitch JA, Pin JP, Fan QR (2012) Structure and functional interaction of the extracellular domain of human $\mathrm{GABA}_{\mathrm{B}}$ receptor GBR2. Nat Neurosci 15:970-978

Geng Y, Bush M, Mosyak L, Wang F, Fan QR (2013) Structural mechanism of ligand activation in human $\mathrm{GABA}_{\mathrm{B}}$ receptor. Nature 504:254-259

Goudet C, Kniazeff J, Hlavackova V, Malhaire F, Maurel D, Acher F, Blahos J, Prezeau L, Pin JP (2005) Asymmetric functioning of dimeric metabotropic glutamate receptors disclosed by positive allosteric modulators. J Biol Chem 280:24380-24385

Hlavackova V, Goudet C, Kniazeff J, Zikova A, Maurel D, Vol C, Trojanova J, Prézeau L, Pin JP, Blahos J (2005) Evidence for a single heptahelical domain being turned on upon activation of a dimeric GPCR. EMBO J 24:499-509
Huang S, Cao J, Jiang M, Labesse G, Liu J, Pin JP, Rondard P (2011) Interdomain movements in metabotropic glutamate receptor activation. Proc Natl Acad Sci USA 108:15480-15485

Jones KA, Borowsky B, Tamm JA, Craig DA, Durkin MM, Dai M, Yao WJ, Johnson M, Gunwaldsen C, Huang LY, Tang C, Shen $Q$ Salon JA, Morse K, Laz T, Smith KE, Nagarathnam D, Noble SA, Branchek TA, Gerald C (1998) $\mathrm{GABA}_{\mathrm{B}}$ receptors function as a heteromeric assembly of the subunits $\mathrm{GABA}_{\mathrm{B}} \mathrm{R} 1$ and $\mathrm{GABA}_{\mathrm{B}}$ R2. Nature 396:674-679

Kammermeier PJ (2012) Functional and pharmacological characteristics of metabotropic glutamate receptors $2 / 4$ heterodimers. Mol Pharmacol 82:438-447

Kaupmann K, Malitschek B, Schuler V, Heid J, Froestl W, Beck P, Mosbacher J, Bischoff S, Kulik A, Shigemoto R, Karschin A, Bettler B (1998) $\mathrm{GABA}_{\mathrm{B}}$-receptor subtypes assemble into functional heteromeric complexes. Nature 396:683-687

Kniazeff J, Galvez T, Labesse G, Pin JP (2002) No ligand binding in the GB2 subunit of the $\mathrm{GABA}_{\mathrm{B}}$ receptor is required for activation and allosteric interaction between the subunits. J Neurosci 22:7352-7361

Kniazeff J, Bessis AS, Maurel D, Ansanay H, Prézeau L, Pin JP (2004) Closed state of both binding domains of homodimeric mGlu receptors is required for full activity. Nat Struct Mol Biol 11:706-713

Kunishima N, Shimada Y, Tsuji Y, Sato T, Yamamoto M, Kumasaka T, Nakanishi S, Jingami H, Morikawa K (2000) Structural basis of glutamate recognition by a dimeric metabotropic glutamate receptor. Nature 407:971-977

Margeta-Mitrovic M, Jan YN, Jan LY (2000) A trafficking checkpoint controls $\mathrm{GABA}_{\mathrm{B}}$ receptor heterodimerization. Neuron 27:97-106

Margeta-Mitrovic M, Jan YN, Jan LY (2001a) Function of GB1 and $\mathrm{GB} 2$ subunits in $\mathrm{G}$ protein coupling of $\mathrm{GABA}_{\mathrm{B}}$ receptors. Proc Natl Acad Sci USA 98:14649-14654

Margeta-Mitrovic M, Jan YN, Jan LY (2001b) Ligand-induced signal transduction within heterodimeric $\mathrm{GABA}_{\mathrm{B}}$ receptor. Proc Natl Acad Sci USA 98:14643-14648

Maurel D, Comps-Agrar L, Brock C, Rives ML, Bourrier E, Ayoub MA, Bazin H, Tinel N, Durroux T, Prézeau L, Trinquet E, Pin JP (2008) Cell-surface protein-protein interaction analysis with time-resolved FRET and snap-tag technologies: application to GPCR oligomerization. Nat Methods 5:561-567

Monnier C, Tu H, Bourrier E, Vol C, Lamarque L, Trinquet E, Pin JP, Rondard P (2011) Trans-activation between 7TM domains: implication in heterodimeric $\mathrm{GABA}_{\mathrm{B}}$ receptor activation. EMBO J 30:32-42

Muto T, Tsuchiya D, Morikawa K, Jingami H (2007) Structures of the extracellular regions of the group II/III metabotropic glutamate receptors. Proc Natl Acad Sci USA 104:3759-3764

Nelson G, Hoon MA, Chandrashekar J, Zhang Y, Ryba NJ, Zuker CS (2001) Mammalian sweet taste receptors. Cell 106:381-390

Nelson G, Chandrashekar J, Hoon MA, Feng L, Zhao G, Ryba NJ, Zuker CS (2002) An amino-acid taste receptor. Nature 416:199-202

Niswender CM, Jones CK, Lin X, Bubser M, Thompson Gray A, Blobaum AL, Engers DW, Rodriguez AL, Loch MT, Daniels JS, Lindsley CW, Hopkins CR, Javitch JA, Conn PJ (2016) Development and antiparkinsonian activity of VU0418506, a selective positive allosteric modulator of metabotropic glutamate receptor 4 homomers without activity at $\mathrm{mGlu}_{2 / 4}$ heteromers. ACS Chem Neurosci 7:1201-1211

Olofsson L, Felekyan S, Doumazane E, Scholler P, Fabre L, Zwier JM, Rondard P, Seidel CA, Pin JP, Margeat E (2014) Fine tuning of sub-millisecond conformational dynamics controls metabotropic glutamate receptors agonist efficacy. Nat Commun 5:5206 
Pagano A, Rovelli G, Mosbacher J, Lohmann T, Duthey B, Stauffer D, Ristig D, Schuler V, Meigel I, Lampert C, Stein T, Prezeau L, Blahos J, Pin J, Froestl W, Kuhn R, Heid J, Kaupmann K, Bettler $B$ (2001) C-terminal interaction is essential for surface trafficking but not for heteromeric assembly of $\mathrm{GABA}_{\mathrm{B}}$ receptors. J Neurosci 21:1189-1202

Pin JP, Bettler B (2016) Organization and functions of mGlu and $\mathrm{GABA}_{\mathrm{B}}$ receptor complexes. Nature 540:60-68

Prosser HM, Gill CH, Hirst WD, Grau E, Robbins M, Calver A, Soffin EM, Farmer CE, Lanneau C, Gray J, Schenck E, Warmerdam BS, Clapham C, Reavill C, Rogers DC, Stean T, Upton N, Humphreys K, Randall A, Geppert M, Davies CH, Pangalos MN (2001) Epileptogenesis and enhanced prepulse inhibition in $\mathrm{GABA}_{\mathrm{B} 1}$-deficient mice. Mol Cell Neurosci 17:1059-1070

Queva C, Bremner-Danielsen M, Edlund A, Ekstrand AJ, Elg S, Erickson S, Johansson T, Lehmann A, Mattsson JP (2003) Effects of GABA agonists on body temperature regulation in $\mathrm{GABA}_{\mathrm{B}}^{-}(-\overline{1})$ mice. Br J Pharmacol 140:315-322

Robbins MJ, Calver AR, Filippov AK, Hirst WD, Russell RB, Wood MD, Nasir S, Couve A, Brown DA, Moss SJ, Pangalos MN (2001) $\mathrm{GABA}_{\mathrm{B} 2}$ is essential for g-protein coupling of the $\mathrm{GABA}_{\mathrm{B}}$ receptor heterodimer. J Neurosci 21:8043-8052

Schuler V, Luscher C, Blanchet C, Klix N, Sansig G, Klebs K, Schmutz M, Heid J, Gentry C, Urban L, Fox A, Spooren W, Jaton AL, Vigouret J, Pozza M, Kelly PH, Mosbacher J, Froestl W, Kaslin E, Korn R, Bischoff S, Kaupmann K, van der Putten H, Bettler B (2001) Epilepsy, hyperalgesia, impaired memory, and loss of pre- and postsynaptic $\mathrm{GABA}_{\mathrm{B}}$ responses in mice lacking GABA $_{B(1)}$. Neuron 31:47-58

Schwenk J, Metz M, Zolles G, Turecek R, Fritzius T, Bildl W, Tarusawa E, Kulik A, Unger A, Ivankova K, Seddik R, Tiao JY, Rajalu M, Trojanova J, Rohde V, Gassmann M, Schulte U, Fakler B, Bettler B (2010) Native $\mathrm{GABA}_{B}$ receptors are heteromultimers with a family of auxiliary subunits. Nature 465:231-235
Suzuki Y, Moriyoshi E, Tsuchiya D, Jingami H (2004) Negative cooperativity of glutamate binding in the dimeric metabotropic glutamate receptor subtype 1 . J Biol Chem 279:35526-35534

Tateyama M, Kubo Y (2011) The intra-molecular activation mechanisms of the dimeric metabotropic glutamate receptor 1 differ depending on the type of $G$ proteins. Neuropharmacology 61:832-841

Vafabakhsh R, Levitz J, Isacoff EY (2015) Conformational dynamics of a class C G-protein-coupled receptor. Nature 524:497-501

Vischer HF, Castro M, Pin JP (2015) G protein-coupled receptor multimers: a question still open despite the use of novel approaches. Mol Pharmacol 88:561-571

White JH, Wise A, Main MJ, Green A, Fraser NJ, Disney GH, Barnes AA, Emson P, Foord SM, Marshall FH (1998) Heterodimerization is required for the formation of a functional GABAB receptor. Nature 396:679-682

Wu H, Wang C, Gregory KJ, Han GW, Cho HP, Xia Y, Niswender CM, Katritch V, Meiler J, Cherezov V, Conn PJ, Stevens RC (2014) Structure of a class C GPCR metabotropic glutamate receptor 1 bound to an allosteric modulator. Science 344:58-64

Xu H, Staszewski L, Tang H, Adler E, Zoller M, Li X (2004) Different functional roles of T1R subunits in the heteromeric taste receptors. Proc Natl Acad Sci USA 101:14258-14263

Xue L, Rovira X, Scholler P, Zhao H, Liu J, Pin JP, Rondard P (2015) Major ligand-induced rearrangement of the heptahelical domain interface in a GPCR dimer. Nat Chem Biol 11:134-140

Yin S, Noetzel MJ, Johnson KA, Zamorano R, Jalan-Sakrikar N, Gregory KJ, Conn PJ, Niswender CM (2014) Selective actions of novel allosteric modulators reveal functional heteromers of metabotropic glutamate receptors in the CNS. J Neurosci 34:79-94

Zhao GQ Zhang Y, Hoon MA, Chandrashekar J, Erlenbach I, Ryba NJ, Zuker CS (2003) The receptors for mammalian sweet and umami taste. Cell 115:255-266 